\title{
La vida es tan corta
}

H acer una película es un acto intelectual ya que esto implica una gran cantidad de escogencias que se deben llevar a cabo además de las decisiones que se deben tomar. De igual forma es un acto artístico ya que el gusto nos dicta estas escogencias y estas decisiones. Es igualmente un acto emocional ya que entra en juego tanto nuestra sensibilidad como nuestra intuición.

Me parece que es un error creer que un cineasta es tan solo alguien que simplemente quiere decir algo. Una película de noventa minutos dice menos cosas que un artículo de periódico de tres mil palabras. Por otra parte, la realización de una película dura alrededor de ocho semanas durante las cuales sólo se llega a grabar dos a tres minutos de película útil por día. A causa de esta lentitud de ejecución por parte del instrumento, pienso que el hombre que quisiera sencillamente comunicar un mensaje urgente, comprendería muy pronto que es más eficaz para él dirigirse directamente a la acción social, política o hacia el periodismo.

No hay que disimular que el que realiza una película se comporta como un niño frente a su juego de construcción: se aísla del mundo y construye uno diferente, acorde a sus deseos y necesidades. Cuando dirige, rodeado de treinta personas, de puntos de focalización mostrando un automóvil persiguiendo a otro, o un hombre que entra corriendo a un ascensor o dos

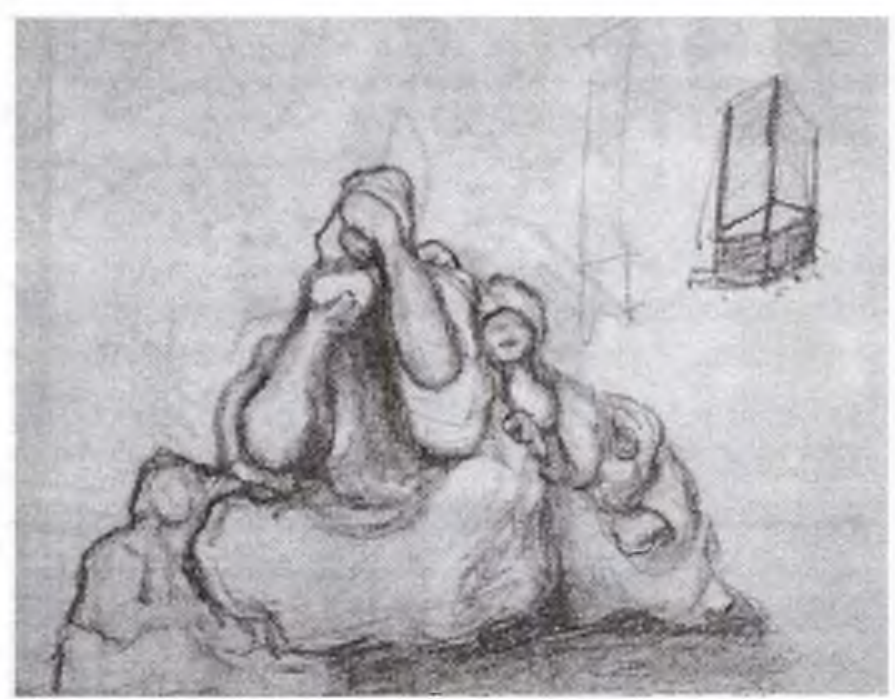

enamorados que acercan sus rostros, el director es un niño, e incluso si rueda una película dirigida a adultos, está animado durante su trabajo por el espíritu de la infancia que nunca ha perdido. No obstante, la concepción, la realización y la terminación de una película ocupan generalmente nueve meses de nuestra vida. La comparación con el embarazo se impone; admito que es fácil al punto de ser un cliché y sin embargo estoy convencido de la verdad de este cliché, en cualquier caso en lo que me corresponde: hago películas para experimentar las emociones de la maternidad y la plenitud que ella otorga.

Puedo añadir que el cine fue en mi adolescencia una suerte de refugio; a causa de esto le profeso un amor casi religioso. No puedo tener por ningún político el mismo interés que por los 
cineastas que admiro y creo firmemente que en la historia de Inglaterra en el siglo XX, Charlie Chaplin es más importante que Winston Churchill.

En resumen, hago películas para sentirme bien y cuando son exitosas, pueden eventualmente hacerles bien a otros, lo que es ideal, ya que el egoísmo y el narcisismo ligados a la creación son un motivo de culpabilidad y de ansiedad para el creador.

Nunca tuve la impresión de buscar una idea para una película ya que cada vez que escogia un tema, significaba que descartaba otros más... La vida es tan corta...Demasiado corta... En mis escogencias descarto la comedia pura ya que la vida no es en realidad divertida, descarto los dramas puros, ya que la vida no es tan trágica, descarto las historias de gánster pues no me agrada ese tipo de gente, descarto las historias policiacas y la de los políticos por las mismas razones. Me esfuerzo por no filmar barcos ni caballos porque me dan miedo, ni personas vestidas de uniforme pues me aburren. Casi nunca muestro personas nadando, esquiando o bailando ya que no sé ni nadar, ni bailar ni esquiar y además los deportes me aburren. Entonces para escoger mis temas, procediendo por eliminación, trabajo con lo que queda: historias de amor e historias de niños. Si un director de películas puede compararse con un capitán de barco a punto de naufragar, adopto el eslogan conocido: ¡Las mujeres y los niños primero! 